\author{
International Journal of Indonesian Philosophy \& Theology \\ 2020, Vol. 1(1): 1-13 \\ (C) The Author(s) 2020 \\ p-ISSN: 2722-8894; e-ISSN: 2722-8886 \\ DOI: $10.47043 /$ ijipth.v1i1.3 \\ https://aafki-afti.org/ijipth
}

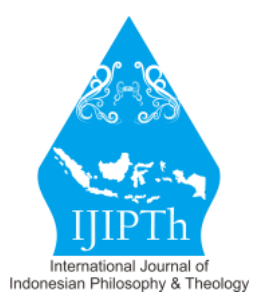

\title{
Manggaraian Idea of "Moral-Self”: Study of Manggaraian Traditional Texts
}

\author{
Fransiskus Borgias \\ Universitas Katolik Parahyangan \\ Email: fransis@unpar.ac.id
}

\begin{abstract}
Western philosophers called the idea of "individual-self" a "modern project". Charles Taylor traced its historical development back to great philosophers of European rationalism (Kant, Hegel, Rousseau, J. G. Herder) with the birth of modern awareness of "individual-self" connected to western-modern individualistic society. Based on a study of "ethical-texts" preserved in Manggaraian oral-tradition, however, I postulate that indigenous tribes have their own way-of-thinking about individual-self, particularly individual-moral-self. Manggaraian people, though mainstream anthropology categorize it communal-traditional society, have some basic knowledge of the idea of moral-self, in the philosophical terminology of Taylor. Strong awareness of moral-self endorses people to have courage to make a personal-individual moral decision (Tillich). Traditional-ethical texts endorse individuals to have their own opinion on important issues of social-moral life, though they will different from the mainstream. Individuals do not depend upon social-communal values. Also in traditional community individuals are endorsed to make their own moral considerations though it means they contradict society. In moral issues individuals should make their own decision. This study traces such tendency in one of traditional community, Manggarai, in Flores, East Nusa Tenggara. It is based on several field research conducted in Manggarai for a project of doctoral dissertation.
\end{abstract}

Keywords: Individual-self, moral-self, Moral life, philosophy, traditional texts, ethical-texts, Manggarai.

\begin{abstract}
Abstrak: Para filsuf Barat menyebut gagasan "individual-self" sebagai "proyek modern". Charles Taylor menelusuri perkembangan historisnya kembali ke para filsuf besar rasionalisme Eropa (Kant, Hegel, Rousseau, J. G. Herder) dengan lahirnya kesadaran modern tentang "diri-individu" yang terhubung dengan masyarakat individualistis barat-modern. Namun, berdasarkan studi tentang "teks-etis" yang dilestarikan dalam tradisi lisan Manggara, saya berpendapat bahwa suku-suku asli memiliki cara berpikir sendiri tentang diri sendiri, terutama diri pribadi moral. Orang-orang Manggara, meskipun antropologi arus utama mengkategorikannya sebagai masyarakat komunal-tradisional, memiliki pengetahuan dasar tentang gagasan diri-moral, dalam terminologi filosofis Taylor. Kesadaran yang kuat akan diri-moral mendukung orang untuk memiliki keberanian untuk membuat keputusan moral pribadi-individu (Tillich). Teks-teks etis tradisional menganjurkan individu untuk memiliki pendapat mereka sendiri tentang isu-isu penting kehidupan sosial-moral, meskipun mereka akan berbeda dari arus utama. Individu tidak bergantung pada nilai sosial-komunal. Juga dalam komunitas tradisional individu disahkan untuk membuat pertimbangan moral mereka sendiri meskipun itu berarti mereka bertentangan dengan masyarakat. Dalam masalah moral individu harus membuat keputusan sendiri. Studi ini menelusuri kecenderungan semacam itu di salah satu komunitas tradisional, Manggarai, di Flores, Nusa Tenggara Timur. Hal ini didasarkan pada beberapa penelitian lapangan yang dilakukan di Manggarai untuk proyek disertasi doktoral
\end{abstract}

Kata kunci: Individu-diri, moral-diri, kehidupan moral, filsafat, teks-teks tradisional, teks-etika, Manggarai

\section{Introduction}

One of the topic proposed for this International Congress was "Engagement with traditional Texts." I prefer to called it with the following title: "Dealing with indigenous texts." Not every indigenous cultures and its people, however, do possess the written texts because usually they are still in the condition of the oral tradition. Therefore, I understand the proposed texts are texts that were recorded 
and preserved in the oral tradition of the indigenous people. Usually they are not written. They are only told from one generation to the other generation. They are only remembered as long as they are told from time to time.

To be sure, there are a lot of texts contained within the space of the oral tradition. Here, I will mainly focus on the texts available within the Manggaraian oral tradition, where I have conducted a field research for my dissertation project back in 2013. More specifically I will focus on the moral or ethical-texts. It is a texts that contain moral exhortations or advices for the life of people. It is a texts through which the local genius delivered their idea for the moral life of the people. Hence they are called the ethical-texts.

And every society in the world want that there will be a law-and-order that will ensure the social life of every member of the society, so that their life will calm, safe, and secure, and do not disturbed or destroyed by the anomalies and chaos. But the law-and-order is only an external instruments, coming from outside. Law-and-order is heteronomous in its fundamental character. It is necessarily enforced forcefully if the compromise and social contract and mutual understanding cannot be realized. The heteronomous law-and-order is only possible if there is an awareness within the individuals or the member of the society. It is the condition in which the so-called personal law-andorder emerged or grew within every individual member of the society itself.

Such a personal law-and-order is usually and traditionally called "moral-self." The antinomy of the heteronomy is autonomy, a norm or a law that coming from the self of the person (hence its etymology in Greek, autos-nomos). The heteronomy is established by the social law-and-order. While autonomy is established with the personal or individual moral-discipline. The personal-moraldiscipline can only be established upon the awareness of a moral-self, a self that has a basic awareness of the moral. Every society has its own system to develop an awareness of moral-self.

Manggaraian people also have their own system to develop it. In this article I want to explore the idea of moral-self exists within the social life of Manggaraian people function traditionally as a foundation for heteronomous law-and-order. The idea of moral-self itself can appear or preserved (recorded) within some moral advices usually delivered by elder people traditionally from one generation to other generation through folk-songs. In my personal opinion some of those moral advices of Manggaraian people are very close to the idealism of the moral-self of modern and western philosophy.

\section{Learning From Western Moral Tradition}

Charles Taylor's article, "The Politics of Recognition" is for me very interesting and important due to the fact that it contains so many insights and inspiration for its readers (Taylor et al., 1994). Surely this is not the main publication of Taylor talking about this subject. There are some other great and important books and publications. For example, Sources of the Self. The discourse on "the politics of recognition" is very important in nowadays multicultural society. The discourse of politics of recognition has changed the previous discourse on the politics of assimilation. In the above text Taylor among other things elaborates the idea of "moral-self." In this study of mine I will mainly focus on the issue of "moral-self". I will apply this study of phenomenon of moral-self on the study of Manggaraian culture and life tradition, which according to some anthropological studies was characterized as the vanishing cultures of the world (Erb, 1999). Though contrary to the personal 
conviction of Erb, this book, however, has been published as one of the great series of the vanishing culture of the world.

According to Taylor in this article the awareness of "moral-self" is a new findings (or discovery) within the history of the development of moral philosophy in European world since the eighteenth century. In other words, he actually wants to say that such moral development and awareness are European in its fundamental character. Then in the historical development Taylor also said that this moral discourse also emerge and develop in the other side of the hemisphere but it is mainly due to the influences of the western thought spreading through the way of modern colonialism and imperialism. So it means that without the history of colonialism and imperialism the phenomenon will not spread through the world. Specifically, Taylor said that the early historical development of such moralthinking and awareness was endorsed mainly by Jean Jacques Rousseau from France and Johann Gottfried Herder from Germany (Gutmann, 1994, pp. 29-30; Taylor, 2001, pp. 134-136; Taylor, 2000, pp. 201-216; Tillich, 1952, pp. 18-20, 23-26, 27, 30).

Let me first elaborate the line of argument of Rousseau. According to this French philosopher and thinker, the moral matter is the matter of following or preserving the natural consciousness within oneself. This natural consciousness was mainly experienced as the principal source for gladness, selfesteem and authenticity of an individual as a person. Again according to Rousseau, this natural- inner voice (a voice coming from within the human being), though exists in the heart of every human being, can also disappear or fade out because of the following two main causes. First, the immaturity (usually in the form of the feeling of dependence on the other people in regards to the moments of taking moral decisions). One is immature in this moment of moral decisions whenever he or she wants to take a moral decision he or she usually depends on the opinion of the other. He or she never be able to stand alone by him or herself as a person with a certain degree of moral consciousness and courage. When the time to take a certain moral important decision come, he or she usually depend on the other's opinion. They will so busy in asking and finding the opinion of the other people. They do not have courage enough to have or to formulate their own personal opinion on the moral issues. Secondly, it can also disappear because of the sin of arrogance. Though Rousseau was not a theologian himself, but as a moralist philosopher he also talked about the theological concept of sin as a hinder toward the personal development toward maturity and authenticity. In this sense Rousseau was in line with the traditional moral thought of Christianity from its origin in Paulinian roots and later on in Augustinian roots as well. This particular sin become one of the basic attitude of human being in general. Therefore, Rousseau says further that the salvation (or safety) of the personal human being is determined by the authentic moral contact with one's own-self, and not so much because they direct the orientation of their moral considerations toward the other people or subject as the main agent for moral decision.

In the Germany world of philosophy, we find the big name of J. G. Herder. But according to Taylor, this man (Herder) actually do not make some new development. Herder only try to sharpen the moral and philosophical thinking of Rousseau. In other words, Herder applies and develops the moralphilosophical thinking of Rousseau in France to his own country of Germany. But it does not mean that Herder has no contribution of his own. According to Taylor, Herder also has his own characteristic peculiar contribution to the development of the western tradition of moral-philosophical thinking. 
Let me describe his specific contribution in the following few words. According to Herder, every human being (person) has their own original and unique way to become a human being, to become a one's own self, or to be a person (in the words of the philosophy of personalism). This unique way lays in their courage to be a moral person. In this process of becoming a human being, every person, says Herder, is unique and original. No one follows exactly the same moral path of the other. Herder further says that self-esteem (the way a person or an individual estimate him or herself) is the specific way of being and becoming oneself. This way of becoming oneself is very unique and einmalich to use a German linguistic terminology (meaning to happens only once in time and history, there is no copy of it, no similarity, no other alias). Herder said that every human being has their own unique way and measurement to become a human being (Taylor, 1994, p. 30).

According to Herder again, this unique way of becoming a self can disappear or failed because of those following two basic reasons: First, because of the pressure (external but also internal) to adapt oneself with the other people outside there. In this case oneself is afraid of becoming a moral self, or in the language of Paul Tillich, a person has not enough courage to be a self (Tillich, 1952). People are usually afraid of becoming different of the other. They tend to become a part of the whole (society, community). Becoming different is a kind of terror for the tranquility of the mind and heart. That is why people in general try very hard to avoid it by becoming more a member of the community (Tillich, 1952, p. 86-112). Secondly, because the individual self (the I) do not have an ability anymore to listen to his or her own internal voice, the voice of the heart. And the reason for this inability is because of many reasons or factors but among other things because of the instrumentalist conviction toward own self (Gutmann, 1994, p. 30). The instrumentalist view of the self has become the reason why people feel afraid of becoming the individual self. In Paul Tillich's word, a person tries to avoid of becoming a person by hiding in the middle of community, in which there is much participation rather than the individual initiatives (Tillich, 1952, pp. 86-112).

\section{Toward Manggaraian Idea Of "moral-self"}

There are a lot of moral exhortations in the cultural daily life and tradition of Manggaraian people. For the detail information on this we can find the interesting information in the book of Josef Ngedot, Kanisius Theobald Deki, and also Adrianus Nggoro, Anton Bagul Dagur. Deki for example make a distinction between those following categories in the Manggaraian oral tradition: tombo adak (adat talk), tombo nunduk (story), tombo go'et (poetical talk or expression), tombo turuk (history), tombo bundu (riddle) (Deki, 2011, pp. 104-114, 115-124, 125-142, 143-158, 159-170). But for the present study I will mainly focus on the following moral advice: "Néka na'as tombo data, néka imbis tombo nipi, néka séngéts tombo wéwét, nia tutus nai rum o lando lekot nai gé". The reason for this choice is that this moral exhortation is the most clear to pointing at the idea of moral-self in Manggaraian moral and religious life tradition.

When I read and seriously study the moral thinking of Rousseau and Herder as is developed further by Taylor, then I remember some moral advices or exhortations within the cultural heritage of Manggaraian people. I think that this moral advice are very much in line with the new moral-vision of the western moral philosophy (represented by Rousseau and Herder). Those two moral thought, endorse me to think about the moral philosophy of Manggaraian people. my main research question based on the inspiration from Taylor's book is "whether they (Manggaraian people) have their own idea of moral-self?" 
After studying some oral tradition (on moral advices) of Manggaraian people so far, I can make a strong conclusion that the discourse on the moral-self was not only the monopoly of European (western) people. Based on the case study of Manggaraian philosophical and moral thinking I can say that the people in the other part of this southern hemisphere also (particularly in this case, Manggaraian people) have their own basic concept of "the autonomy of moral-self."

In this particular moment, I try to explore the case of the idea of the moral-self as far as it is realized by Manggaraian people, in Flores, East Nusa Tenggara. That is the main subject matter that I want to elaborate in this paper. I will try to elaborate such basic idea by making a discourse-analysis of the treasures of Manggaraian oral tradition. One of the moral advice of Manggaraian people strongly, according to me, points to the idea of the "autonomy of moral-self." To prove this statement I will try to show some expressions in Manggaraian language that express such a truth. Moral discourse and advice of Manggaraian people usually expressed in the form of folk-songs usually sung in communal gathering, or ritual or any other traditional feast or celebration. First of all I will quote it. After that I will try to explain and elaborate the meaning and its process of constructing meaning. The discourse goes like this:

Tabel 1. Ideas of Self-Moral Autonomy

\begin{tabular}{|c|c|}
\hline First part of the moral advice & Its repeated responsorial part \\
\hline $\begin{array}{l}\text { Do not preserve what people says } \\
\text { (Néka na'as tombo/jangka data) }\end{array}$ & \multirow{4}{*}{$\begin{array}{l}\text { Just keep and lean on your own mind and } \\
\text { heart, (Nia "tutus" nai rum) } \\
\text { Be humble always oh my heart. (Lando lekot } \\
\text { nai gé). This is only an almost literal } \\
\text { translation of the Manggaraian version of the } \\
\text { moral advice. And this is its original version } \\
\text { in Manggaraian language: Néka na'as } \\
\text { tombo/jangka data, nia tutus nai rum. Néka } \\
\text { imbis tombo nipi, nia tutus nai rum. Néka } \\
\text { séngéts tombo wéwét, nia tutus nai rum. Néka } \\
\text { na'as tombo warat, nia tutus nai rum. Nai } \\
\text { rum é lando lekot, lando lekot nai gé. Its } \\
\text { English version could be found in the box } \\
\text { above. }\end{array}$} \\
\hline $\begin{array}{l}\text { Do not believe in sayings from a dream } \\
\text { (Néka imbis tombo nipi) }\end{array}$ & \\
\hline $\begin{array}{l}\text { Do not listen to the sayings brought by the } \\
\text { blowing wind. (Néka séngéts tombo } \\
\text { wéwét) }\end{array}$ & \\
\hline $\begin{array}{l}\text { Do not preserve sayings that brought by the high } \\
\text { wind. (Néka na'as tombo } \\
\text { warat). } \\
\text { Note carefully the form of those four lines of the } \\
\text { moral advices. They follow the pattern of } \\
\text { similarity of sound in Manggaraian language. For } \\
\text { example, the word na'as...has a similar sound with } \\
\text { data., or the word imbis has a similar sound with } \\
\text { nipi..., or the word séngéts has a similar sound } \\
\text { with wéwét, and finally between na'as and warat. } \\
\text { In the first pattern, there is a dominant sound as a } \\
\text { main characteristic that is the letter } A \text { (in na'as, } \\
\text { data). In the second pattern, there is a dominant } \\
\text { sound of letter I (in imbis, nipi). In the third } \\
\text { pattern, there is a dominant sound of letter } E \text { (in } \\
\text { séngéts, wéwét). In the fourth pattern, there is a } \\
\text { dominant sound of letter } A \text { (in na'as, warat). In } \\
\text { the middle of those main dominant pattern of } \\
\text { similarity of sound there is the word tombo. }\end{array}$ & \\
\hline
\end{tabular}


The first line can be translated in the following expressions: "Do not keep or preserve the words of other people." The word tombo in Manggaraian language can also be changed with the word jangka. Both have basically the same meaning, that is sayings, discourse, or opinion. But usually the word jangka means to make an interruption or intervention or even made a criticism toward the other people's opinion. Such a meaning for example can be easily seen in the following usage: "Do not comment other's house, you must cover first your own house with a roof". Or in its Manggaraian version: "Néka jangka sékang data, olong bubung sékang rum". In Indonesian version it can be translated in the following expression: "Jangan kritik rumah orang, sebelum anda mengatapi rumahmu sendiri." I found this expression first of all from my field research back in 2013. But then I also find this expression in Manggaraian Dictionary of Father Verheijen (1967, p. 99). I also found it in the collection of Manggaraian Texts of Father Jilis Verheijen. The word tombo itself usually has these meanings: tale, story, myth, legend, even history. But in the word tombo there is no connotation of interruption, intervention, or even the coercion of the will. Those two words can have the following meaning: opinion, vision, or the other people's consideration.

Then let me elaborate the word $N a^{\prime} a$. Basically this word (na'a) has the following meaning: to keep, to preserve, to protect, to treat, to remember in a strong way. Néka means "do not". So, néka $n a$ 'a(s) means "do not believe in" and "do not lean on the opinion" (stance) of other people without critical mind. The demand will become relative when it is related to the moment of taking decision. Every decision (decision making process) should always be autonomous, conducted by the person him or herself, conscious, and mature (taken as a mature person). Manggaraian word data has a close relationship with the root word of ata which means people or person. Here it is a people in general; he or she is not specifically identified as a subject of an ethical responsibility. It is, therefore, difficult to be taken as a stronghold or foot basis. Data here means people (anonymous person in general). They are not an identified subject. They are not specified subject of an ethical responsibility. Therefore, they cannot be made a stronghold for decision making process. They are not reliable. If people believe or rely on such person, there can be a serious problem in the time to come. They cannot be confirmed, verified, or clarified. In the process of learning, it is absolutely necessary to have an opportunity for verification, confirmation, and clarification. If the person is not clear, that is the ata, then it is very difficult to ask for information and especially the responsibility.

The second line of the moral-advice can be translated as the following: "Do not believe in the words heard in or through the dreams." Literally, tombo nipi means, the stories coming from the dream. And because they come from a dream, so they do not came from the real world. The meaning is "what is heard in the world of dream", or "whatsoever that can be heard, seen when people are dreaming". It can also be translated as the "delirious of sleeping person", usually heard by other people. So the dream has two sources: the dream of oneself, and the dream of the other. Whatever its sources, both sources still cannot be taken as a foundation for the process of taking moral decision. Dream is, however, dream. We can discuss longer (wider and deeper) about the dream phenomenon. But, because the dream came from the world of sleep, from the world of sub-consciousness (in the Freudian and Jungian meaning of the word), then it cannot be made as the basis for moral decision.

It is still strange enough, however, that though there is already such a local wisdom in the treasure of Manggaraian people and their cultural heritage concerning the dream, people still try to find the source of inspiration from the dream whenever they want to involve in a gambling (especially the 
gambling of togél, a kind of lottery in Indonesia). Maybe the main reason for that phenomenon is the fact that in other contexts, dream also can be seen as the medium to know and discern the will and the plan coming from the world outside, the world beyond. In theological language it is said that the dream can be used as a means for revelation. It is sometimes believed by the people that God deliver and reveal his plan and will through the medium of dream of human being. In Yudeo-Christian Biblical tradition, we can find the vision and conviction that dream is the medium for revelation. God and supernatural beings, is believed to express their will to human being through the medium of dreams. For example, we can find the dreams of Jacob (Gen. 28:10-22), Joseph in the Old Testament (Gen.37:5- 11), the dreams of Joseph in the New Testament (Mat.1:20; 2:13; 2:19), the dream of Paul, the dream of Peter, and some other examples.

The third line can be translated in the following lines: "Do not listen to the discourses" (néka séngéts) that brought by the flowing wind (tombo wéwét)". In other words, do not believe in gossips. In these categories we can add the words like rumors, scuttlebutt, or tittle-tattle. All of these do not have any valid authority. They do not strong enough as a source or a basis for moral decision. Using another variation words of the wind especially the strong wind, we can translate the fourth line in the following expression: do not keep or preserve (néka na'as) the words that have been brought by the strong wind (tombo warat). The basic meaning of the fourth line does not totally different from the third line. Basically we are asked not to listen to or pay attention to the sort of discourses that has no real and clear sources of a person who can responsible for its consequences. They, therefore, cannot be used as a basis for making moral decision and consideration. This kind of discourse (tombo) is included in the discourse (tombo) that has no clear source and the person who will responsible for it. Moral decision was very important for the life of human being. It is hoped that our moral stances are not determined by other people or by society in general. We should decide for and by our-self. That is the real meaning of moral-self.

\section{Just Follow The Voice Of Your Own Heart}

If those ways and means of getting knowledge has been prohibited (néka, do not) then what is left to be used as a compass for the life of people? This question is important and we should answer it because the answer will determine people's life. If there is no answer to this important question then there will be a lot of problem. For example, people will crumble into confusion, chaos, and despair. Therefore, this negative imperative (néka, do not) should be followed by something positive imperative, that the people will have something to hold on. For example, people should add that if we reject all of those prohibition, then people should be endorsed to strongly hold on something positive, should be given a positive imperative. In this particular moral-case, people are endorsed to hold on one's own personal consciousness, to the voice of inner mind. In this case people should follow their own mind in an obedient way. That is the meaning of Manggaraian expression, "Nia tutus nai rum." In the following part I try to make an exposition of the literal meaning of the expression.

Literally this expression of "Nia tutus nai rum," can be analyzed in the following way. Manggaraian word nia actually means "where" or may be better in this context "what". Tutus means "decide" or "determine". Nai means soul, mind, heart. Rum means your own, by your own self. Then "nia tutus nai rum" means what has been decided by your own-self, your own mind, your own heart, your own soul (without any external push). 
In oral tradition, there is no clear, established, standardized, and written norm for pronunciation of words. Therefore, the word tutus often undergo some changes and variations in its spelling or pronunciation. For example, in one place and tradition this word tutus has been spelled with another variant of tutup and hence the expression nia tutup nai rum. But in this article I will use the word tutus rather than the word tutup. Usually the word tutus can have a meaning of something that has been considered with a certain level of maturity and it is conducted by your own self. But the problem is that the word tutus cannot be found in Manggaraian Dictionary of father Verheijen SVD. Related to this issue I can say that father Verheijen's dictionary did not include all of Manggaraian words yet. There are still a lot of Manggaraian words that stay outside of the reach of this Dictionary. In that Manggaraian Dictionary we can only find the word tutup and tutur.(Verheijen, 1967, p. 665) The word Nai refers basically to the center of intellectual activity. But it can also refer to the heart as well. Therefore this word nai can also mean something that has been thought in a very mature way. Literally, the word nai means soul, mind, intellect, the center for moral decisions and consideration.

Maybe in old Manggaraian oral word-list (not a written Dictionary), the word tutus derived from the word téti (literally means to raise up, to hold up; but it can also mean to start to walk and go). This word téti can be found in its popular usage in the following expression: "nia téti nai rum." It means "what has been considered by your own mind and heart." "Teti" means to raise up, to hold up. But here the word téti means the dynamic movement of the heart to put forward its opinion or to put forward its evaluation and consideration on something. It can also means the voice of your own mind and heart, the internal voice of the heart. This original tutus, derived from tééti, has been replaced by the word tutup so that the word tutus disappeared from its daily uses. It has been replaced by the word tutup. It should be realized that the word tutup is not the word from Indonesian language, meaning to shut down. On the contrary this word tutup is a Manggaraian word. Its basic meaning is something that has been finally decided by a person. There is no other possibility to determine the meaning of this word.

If something has been decided in a final way, then there is no possibility of the other way of thinking. In this case the other course has been closed or severed. In this case individual person should not be shaken by external influences coming from other people, or by the opinion of the other, or the words of the other. Surely it is good also to listen to them. But finally in the realm of moral decision and consideration, our consciousness should be autonomous, firmly strong stand upon its own self, and be courage to decide something. While in the later development, people nowadays usually pronounced the word tutup whenever they sing that tradition volk-song. So instead of saying Nia tutus nai rum, we heard the following expression of Nia tutup nai rum. Actually its basic meaning is still the same. But in my personal consideration I tend to choose the word tutus (totos) instead of tutup. This choice is meant to avoid the confusion of this word tutup with the word of Bahasa Indonesia.

To be sure this is one of the main problem with the oral language: there is no stable model for writing of a certain words (in the example is the word tutup and tutus). The words in the oral tradition develop in a dynamic way through its own laws. On the one hand, there is something positive related to the fact that there is no written formal standardize tendency to be authoritarian because of the written norm or law. While on the other hand there is also its negative aspect that is the fact that there is no final form of an important word and concept. It always develops and change according to the flow of time and history in the usage and the process of pronunciation by people who use the language. Within this whole great process there is also a mishearing or mis-listening undergone by the 
participants in the dynamic of the dialogue. All of this phenomenon is the constitutive and integrative process of the becoming of the language itself. The role of the daily user of a language totally determine the fate of the language in particular.

\section{Becoming Humble Always}

Now in this part I want to explain and give meaning to the final part of the above moral exhortation in the treasure of Manggaraian people. The last part goes like this: "lando lekot nai ge." What is the meaning of this expression that we find in the repeated part at the end of those above four lines of moral advices? Let me explain and explore words by words (verbatim). Lando basically means flower (Verheijen, 1967, p. 248). In Manggaraian language there are two words for flower: lando and wela. The word Lando is usually used for sugar can (teu), or the wild sugar-can (polor in Manggaraian language), rice (woja), corn (latung). While the word wela (Verheijen, 1967, p. 741), is used for the flower of mango, jackfruit, pumpkins, gourd (labu), and papaya ( $\left.k a^{\prime} u n g\right)$.

In my opinion the original author of this traditional folk-song contained the above moral advice have consciously chosen the word lando instead of wela to be used in this moral song. The very reason for that choice is that the observation upon the natural phenomenon of the physical development of lando itself. This development is something very special. It is totally different from the development of wela. Let me take the example of lando woja (the flowering process of paddy in rice field). When the grain of the paddy has become more and more full, the lando of paddy will start to bow down because of its weight. The bowing down process of lando is called lekot in Manggaraian language. I think it is this observation that is expressed and preserved in this folk-song.

This Manggaraian traditional expression of phrasal words, can be easily compared to classical aphorism of Melayu heritage: "Bagai ilmu padi, kian berisi kian merunduk". (Like the characteristic of rice, when it is full it will bow down). To bow down one's head is called lekot in Manggaraian language (Verheijen, 1967, p. 270). The aspect of "bow down" can be seen in the word of lekot which means to bow down because of the fullness and the ripeness of paddy grain. On the contrary if the grain of paddy was infected by plant-disease (pest) (in this case by nengep or rice-pest), then the grain will become dry and empty. The dried grain will become white and pale and it will stand straight up to the sky (sedek), grows vertically like its main plant. Such phenomenon usually gives farmers a clear sign that the grain is empty. No rice. When it is infected by rice-pest, then there will be no phenomenon of lando lekot, the bowing down of the grain of the rice, because the grain still stands straight to the sky because it is empty.

My critical question is, why those four lines of moral exhortations should be ended with this knowledge of lando-lekot? It is not easy to answer this question. But one of the rational explanation in my personal philosophical exploration runs as the following: if someone has become so much going deep down into his or her own consciousness and inner voice, then such a person will become more and more humble, more and more bowing down in his or her body language, or lando lekot in Manggaraian language, bowing down like the full grain of paddy. The internal journey, the journey toward the soul, toward the mind, toward one's own soul, the journey to the "palace of nowhere" to use Thomas Merton's theological concept, will make the subject become more humble and humble, to become more mature in humility. When I write this particular part of the paper on humble and humility, I immediately remember the practices of humility of Saint John Paul II; whenever he visited the land, he always first of all kiss the soil in that place. I also remember the practice of prayer of the 
Jewish people, and Moslem people, bowing down their body to the ground. And I remember also the practices of prayer of Christians (especially Catholics) in kneeling down, bowing down the body, etc. So bowing down is something very universal practice of human being to show the basic attitude of humility. That person will not become arrogant. Whenever people are brave enough to listen to his or her own internal voice, he will become more and more humble. Humility will become his character, his attitude, and the tendency of his/her mind and soul (nai). That is why in Manggaraian language it is called lando-lekot nai ge, meaning "oh my soul may you become more and more humble" in your progress and development.

\section{Between "Moral Formation" and "Moral Decision"}

There is a great difference between the process of "moral formation" and the moment of "moral decision." The first is a matter of educational process. The second is a matter of a moment of showing the ability and the maturity to make a moral decision, the moment of showing oneself as mature moral being. If people, however, should make the consciousness a point of reference for the moment of final moral decision making process, it does not mean that people want to relativize the existence and the presence of the other, their opinion and their moral considerations. No, it is not. However, their presence is very important because the substance of the process of education and formation is to direct our attention and focus toward and listen to the other, listen to the teaching (or toing in Manggaraian language) and guidance (titong) from other people. Listening to and accepting the teaching and the guidance of the other do not only apply to a certain stage in the human development, mainly when they are still very young (as a child and teenagers). No. It is an eternal obligation for the life of human being.

The process of moral and intellectual formation necessarily need a lot of assistance of the other. In this matter individuals do not autonomous at all. In this matter they are absolutely heteronomous (depend on other people). People need the insights and critical help of the other to develop and change. It is here that people needs the inputs that can only be received through various lessons both formal and informal. Those things also can be received from social interactions with other, even from enemies and person whom we do not like. This process of formation never become final. It is always in the process of making and becoming. That is why it is officially called on-going- formation, the formation that was continually pursued by the person for the sake of their development and progress in life. In the old time, this phrase of "on-going-formation" was also known with its alias, long-lifeeducation. It is a continuing process (education) that last during the whole life of a human being until the end at the moment of dying itself. At that time, they will arrive at the terminal.

In the process of moral formation for the consciousness we absolutely need the help of other people. In this matter we are not autonomous. In this case we are absolutely heteronomous in the sense that we still need inputs and insights, advices and exhortations of other people. In this matter we need a lot of help and insights so that we can know much more and more and finally we become mature as human being. The more we receive inputs and insights from other people then the more also we get a new and greater perspectives that can enrich the individual in various aspects of knowledges and visions. In this connection we have to see and imitate the best examples and practices from other people. In this connection we have to imitate the development and the progress of other people toward something positive. 
Manggaraian people really realize these things. That is why this truth also can be found in the traditional expression of Manggaraian language: “majun lélo tau." It means that we can only undergo some development and progress because we see and imitate other people and learn something new and positive from their life experiences. There is no negative connotation in that expression, though maybe there are some other people who think in that direction. So in this case, people need what we usually call in the modern time, a comparative study, for the sake of development and progress and also for the sake of the increase of the quality of knowledge. This insight can be traced in the following traditional expression of Manggaraian people: "Don lako don ita, don ita don baé, don baé don ngancéng pandé, don pandé don ngancéng campé." In Indonesian language it can be translated in the following expression: "Makin banyak berjalan, makin banyak melihat. Makin banyak melihat, makin banyak tahu. Makin banyak tahu, makin banyak berbuat sesuatu. Makin banyak berbuat sesuatu, makin banyak bisa membantu." Its English version has been given in the texts above. Its Manggaraian original expression also has been given in the body of the texts above. Literally it can be translated as the following: "The more you make a journey the more you will be able to see, the more you see the world, the more you will be able to know, the more you know, the more you can do something, the more you can do something, the more you will be able to help".

Such a moral advice was directed or given to mature person who are hoped to be independent in their conduct and moral decision. This kind of advice was delivered by people when there appears a conflict of interpretation (Paul Ricoeur) and in the moment of decision making. The maturity and adulthood of a person was determined by and can be seen from their moral courage. To listen to, pay attention, and consider the opinion and perspective of the other is important, but the determining factor is still our own self, and not the other person. It is always said that within "moral formation" people should listen to the other people (especially in this case the voice and the perspectives of the formator). But in the process of taking/making "moral decision", it is our-self who should become the subject of our decision, and not the other people. To say it in the other way, within the moral education and formation we are depend on other people. While in the moral decision we are actually autonomous. The moral education or formation should be directed toward the attitude of humbleness: in this case, to use Manggaraian expression, we should become more and more bow down (lekot) because of the fact that the it should have a heavy grain. It is not only look around (conga/songak/jongang) because it is the sign of ignorance of that person.

Differ from the process of moral and intellectual formation, the moment of intellectual and moral decision should be autonomously decided. For example, the decision about the way of life (whether to marry or celibate), or the decision about the intellectual decision in answering a question in the examination. In this matter people should decide something as an autonomous adult. Surely people can also answer the question in examinations with their own ability but it can also be answered by way of cheating. The quality of the way to answer should be decided by individuals in an autonomous way. It is here that people enter into the realm of moral consideration. And the moral decision and consideration should be rational. Traditionally in ethics it is usually called the rationality of the consciousness. Consciousness should always be rational.

\section{Conclusion}

Though in this study I mainly focus on the case of Manggaraian, but to be honest this awareness of individual-self is not the monopoly of the Manggaraian alone here in Indonesia. Based on a short and 
light discussion, I may say that the awareness of the idea of moral-self can be found in various traditional community in Indonesia. In discussion with my students coming from various cultural backgrounds, I eventually realize that there are some expressions used by indigenous people to formulate such awareness. Students coming from Javanese background for example put forward two examples. First is "ngono-ngono, ya aja ngono!" It is not so easy to translate this expression. But to make it simple it can be translated freely with the following expression: However the actual-recent situation has become crazy and deteriorating, individual should not absorb or sink into it. Individual should have a courage to go beyond such deteriorating condition. Second is "sembada" (sometimes could be used with a prefix swa, hence swasembada). This expression also cannot be easily translated. But one of the suggestion of my student is consistency or being consistent in attitude. But beyond this expression there is a nuance of meaning of freedom necessarily accompanied by responsibility. Based on the discussion with Rio (from a mixed background of Javanese and Ambonese) and also the contribution of Beny with his friends coming from the same minor seminary, Mertoyudan.

The aspect of individual responsibility could be attested also by witness from Nias background represented by Rahmat Waruwu. From him I got the following expression: Khöu mbagi mbölökhau. Its literal meaning is that the result of your manual work is your own. It means that the individual is responsible for his or her life once he has reached the aged of over eighteenth (having finished their senior high school). There are also some other testimony coming from the students from Ende and Bajawa (Riung) backgrounds and also some other people claiming to have no certain particular cultural back-ground. For example, Aufar, Denis, Roy Rado, etc. The other expression I found from the contribution of a student coming from Batak cultural background. He said that Batak people have their own traditional expression of communal and social solidarity rather than an individual idealism. This ideal, he said, is preserved in the following expression: "Martibung rap to toru, marlompat rap tu ginjang." The meaning is that when we fall down we have to fall down together. And when we try to leap up we have to leap together. An individual cannot and should not act for his or her own self. Everything should be done together. In the case of a dilemma usually people will come to the authority of the first-eldest son, "anak panggoaran". Every parties in the agreement will receive their own proportional portion, their own peculiar rights (dalian natolu). If there is still a problem that cannot be decided on this level then people will go to elder people, for example to tulang asking for help and advice (somba marhula- hula). This elaboration is also based on the discussion with a student, Lamro Siregar, coming from the background of Batak.

Finally people should responsible in a rational way for their own life and future. They should shoulder the consequences of what they have decided and done in their life. That is the individual and personal responsibility. The mature person and the person with a rational thinking, should not avoid from such kind of responsibility. The personal responsibility cannot be represented or given to the other party because it is closely related to the individual person itself.

Father Franz von Magnis Suseno, a moral philosopher from Sekolah Tinggi Filsafat Driyarkara Jakarta, call this matter with a name of the autonomy of consciousness. And this is one of the definition of such autonomy, based on the formulation of Magnis Suseno (and I try to paraphrase it in the following way): "It is a condition in which the individual, whenever they are challenged by one moment of ethical decision, should be brave or courage enough to take a decision and he or she has to make it in a conscious and autonomous way. In this matter the individual person should not just looking around for help or try to find any assistant. Now and here the individual are called to stand in 
his own self and in an autonomous way they are called and challenged to enforce their autonomy in a certain ethical moment of decision,"(Suseno, 1975).

The obedience toward this moral autonomy is the sign of maturity and adulthood of someone in a moral concern. That is a clear sign that they own the wisdom of life. Such wisdom will reach its peak development within the humility, the humble mind and heart. Because according to one of the old sayings, it is said that "the beginning of wisdom is the fear of God," (Ps 111:10; Pro 1:7; 9:10). And it is interesting enough as well that its peak also is in the fear of God. So, it should be directed toward the attitude of humility.

\section{References}

Deki, K. T. (2011). Tradisi Lisan Manggarai, Membidik Persaudaraan Dalam Bingkai Sastra. Jakarta: Parrhesia Institute Jakarta.

Erb, M. (1999). The Manggaraians: A Guide to a Traditional Life Style. Singapore: Times Edition.

Gutmann, A. (1994). Multiculturalism, Examining the Politics of Recognition. Princeton, New Jersery: Princenton University Press.

Suseno, F. M. (1975). Etika Umum: Masalah-masalah Pokok Filsafat Moral. Yogyakarta: Kanisius.

Taylor, C. (2001). Sources of the Self, The Making of the Modern Identity. Cambridge, Massachussets: Harvard University Press.

Taylor, C. (1994). "Politics of Recognition", in Amy Gutmann (ed) 1994, Multiculturalism, Examining the Politics of Recognition, p.25-74.

Taylor, C., Appiah, K. A., Habermas, J., Rockefeller, S. C., Walzer, M., \& Wolf, S. (1994).

Multiculturalism: Examining the Politics of Recognition (Revised edition; A. Gutmann, Ed.). Princeton, N.J: Princeton University Press.

Taylor, M. C. (2000). Journeys to Selfhood. Hegel and Kierkegaard. New York: Fordham University Press.

Tillich, P. (1952). The Courage To Be. New Haven and London: Yale University Press.

Verheijen, A. J. (1967). Kamus Bahasa Manggarai. 'S-Gravenhage, Martinus Nijhoff: KLTLV. 